\title{
Development of Teaching Materials Based on Technology Literacy Through the Website for PGSD FKIP UHAMKA Students
}

\author{
Khoirunnisa Pertiwi ${ }^{1, a)}$, Mimin Ninawati ${ }^{2)}$ \\ ${ }^{1)}$ Universitas Muhammadiyah Prof.Dr.Hamka \\ ${ }^{2)}$ Universitas Muhammadiyah Prof.Dr.Hamka \\ ${ }^{\text {a)} C o r r e s p o n d i n g ~ a u t h o r ~: ~ p e r t i w i @ g m a i l . c o m ~}$
}

\begin{abstract}
This study aims to develop literacy-based teaching materials through a website called BAGUR'SD for PGSD FKIP UHAMKA students, and to find out the quality of this product that has been produced so that it is suitable for use in the learning process on campus. The research method was carried out in two stages, namely observation and the Research and Development (R\&D) method. The observation method was carried out to determine the learning process in the classroom and the use of students' smartphones while in class and during Work From Home (WFH). Methods (R\&D) or research and development adapted from the Hannafin And Peck development model were used to develop the BAGUR'SD website. This website was tried out for active students of PGSD FKIP UHAMKA. The results showed that the technology literacy-based teaching materials through the website that had been developed based on material experts obtained a percentage score of $89.28 \%$ with a very good category seen from the usefulness of the website to help lectures, then the results of validation by media experts obtained a percentage score of $88,73 \%$ with the very good category saw the opinions and suggestions of experts regarding the website. The trial was conducted on active students of PGSD UHAMKA. The results of the quality of learning media were $88.49 \%$ with a very good category seen from the many who accessed the website. Based on the results of data acquisition, it shows that the development of technology literacy-based teaching materials in the form of a website is suitable for use as a learning resource for PGSD students.
\end{abstract}

Keywords: Teaching Materials, Technology Literacy, Website.

\section{INTRODUCTION}

The world is experiencing rapid development in the field of technology and influencing many aspects of people's lives. The transformation that occurred had an impact on the development of large-scale and complex world technology. Now the world is moving very fast and interconnected, where the changes of technology, politics, economic, demographic and teacher are fast and massive. Experiencing rapid development has changed many educators' perspectives.

The changes that has been made are not only about teaching, but far more essential, it is a change in the perspective of the educator concept itself. Educators must be able to prepare prospective educators (students) to be able to use technology in order to create students who are ready in the midst of a technology-filled industry. As well as elementary school which is a phase in basic education. 
Basic education must be able to adapt to the full technological industrial revolution era, otherwise, society will have difficulty continuing to a higher level.

The advancement of information and communication technology is irreversible. Described in Ninawati [1] the very fast development of science and technology can be affected by individual mindset, behaviors, and habits. To implement this technology in education, efforts are needed to understand the technology itself. One of them is by promoting the technology literacy movement in students so that they are ready when they are involved in the world of education, not just sitting in the chair of lecture.

Low literacy makes a lot of effort to improve it. One of the efforts to improve the literacy skills of students is carried out by developing a school literacy movement Ninawati [2]. Literacy is expected to be able to improve advanced writing skills where students are able to express thoughts, feelings, and information in the form of conversations, instructions, and stories.

This literacy is related to the campus efforts to develop innovation in education. Developing innovation is an important part of literacy because the greatest feature of human when compared to other creatures lies in his ability to think as a cultured human Ninawati [3]. There are various campus activities that can be used as an effort to develop these technological literacy skills. Through this literacy, the way students view the world of education which is increasingly advanced is not a problem but answers the challenges that arise.

The definition of modern literacy is the ability to read, write and arithmetic (count), use language, numbers, pictures / illustrations, computers and other basic elements to understand, communicate, strengthen useful knowledge and use the dominant cultural symbol system. Literacy according to UNESCO [4], is the ability to identify, understand, interpret, create, communicate and calculate using printed and written materials in relation to various contexts.

Literacy is the right thing to be used as a place to promote knowledge and be ready for the new world. Literacy combined with technology creates a broad perspective in order to answer the challenges that occur in the world of education. Technological literacy is the ability to use, understand, organize, and assess an innovation that involves process and science to solve problems and expand one's abilities Maryland State Department of Education [5].

The challenges that will be faced by elementary school teachers in a technological era must have been prepared since producing prospective teachers who will bring a flow of change for students with technology that cannot be separated in today's teaching world. The challenges in the future will be more stringent so that education graduates are needed who are not only skilled in one field but also creative in developing the occupied field
Ninawati [6]. One of the challenges that the prospective teacher student must face in preparing teaching materials is how to provide interesting and meaningful learning so that the goals of education can be realized. Where we obey the many components in it.

Teaching materials are learning resources which until now have played an important role in supporting the learning process. Teaching materials are a set of learning tools that contain learning materials, methods, limitations, and ways of evaluating which are designed systematically and attractively in order to achieve the expected goals, namely achieving competence or subcompetence with all its complexity Lestari [7]. It is in line with the Ruhimat which states that learning materials are basically the "content" of the curriculum, namely in the form of subjects or fields of study with topics / subtopics and their details. Ruhimat [8]. This understanding explains that a teaching material must be designed according to government regulations and the desire of students to help the learning process.

In addition, the shift in teachers who were initially the only learning resource and currently leading as facilitators demands the presence of a teaching material / handbook to bridge the problems of the limited absorption ability of students and the limited ability of teachers in managing the learning process in class. Obtaining teaching materials with a familiar appearance such as printed teaching materials in the form of handouts, books, modules, brochures, which are still widely used in the middle of sophisticated education wrapped in technology is deemed ineffective and efficient and difficult to collect in one unit

This ineffective form of printed teaching materials has switched by developing, designing a product in the form of Elementary School teaching materials from grade 1 to grade 6 based on a Website that can increase literacy in terms of technology for students, opening horizons to intersect with the sophisticated world of technology. Website-based learning is one part of the example of electronic learning (e-learning) using internet technology as a learning tool Ridwan [9]. Simplify the teaching materials that are contained in one website in which there are components in teaching. The forms of teaching materials scattered with printed media are contained in the link address that has been designed by the researcher.

The role of students is very important to improve and adjust the absorption of students with the availability of teaching materials that are ready to be applied to students.. Students can develop and enrich the learning experience of students with creations in the form of other activities that are relevant and adapted to the potential of students in their schools with the teaching materials that have been developed in the form of a website. Easy search and selection of the right teaching materials become a provision for students to teach and educate students with their creativity. 
Efforts to improve student learning resources can be done with technology literacy-based teaching materials through the website to make it easier to select and create teaching materials. Therefore, teaching materials in the form of this website are here to provide knowledge about the development of technology literacy-based teaching materials.

\section{METHODS}

The method used in this research is the development method or more often we know it as Research and Development (R\&D). R\&D generally focuses on the process of developing and validating educational products. In accordance with the name, Research and Development is understood as the power of research that starts with Research and continues with Development. Research activities are carried out to obtain information about user needs. While development activities are carried out to produce learning tools in the form of a website which contains teaching materials. In this R\&D research, researchers used the Research and Development (R\&D) method according to Winarni [10] is a process or steps to develop a new product or improve an existing product so that it can be accounted for.

In this R\&D research, the researcher used the Hannafin and Peck style. Hannafin and Peck's style is a learning design model that consists of three phases: (1) needs analysis phase, (2) design phase, (3) development and implementation phase Yuli Yanti [11]. In Hannafin and Peck's style, grading and repetition need to be carried out in each phase. As illustrated in the following chart.

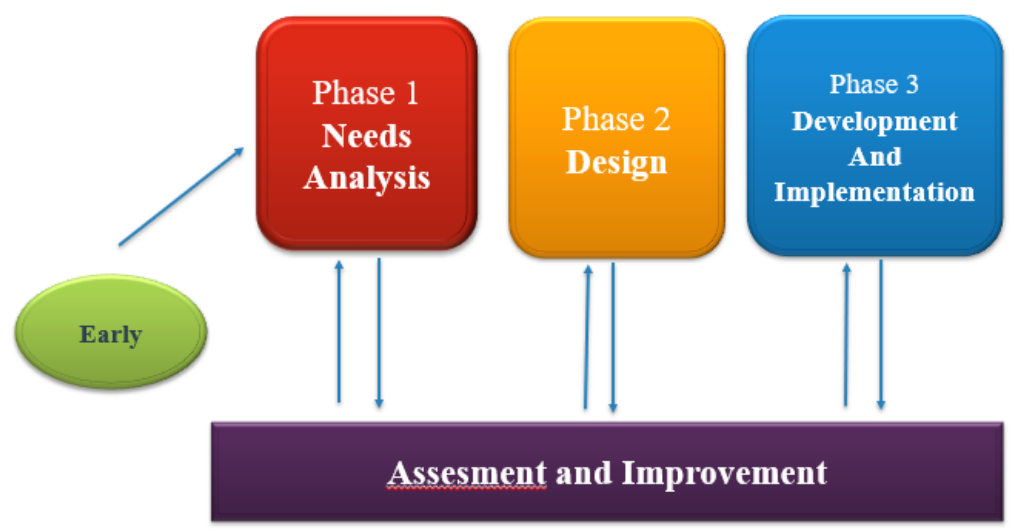

FIGURE 1. Hannafin \& Peck Style

Several data sources in this study used a questionnaire, from media experts, material experts, and respondents. According to Sugiyono [12], data collection was carried out by giving a set of written questions to respondents to be answered. The questionnaire is used to measure the quality of the media being developed. The questionnaire instrument in this study was used to obtain data from media experts, material experts, and respondents as materials for evaluating the learning media developed. In writing this questionnaire using a Likert scale. Data collection procedures on the development of instructional media using qualitative and quantitative data. Qualitative data is in the form of suggestions and input from media experts and material experts. Quantitative data in the form of assessment data on Android-based learning media from material experts, media and respondents.

Sources of data in this study were 5 experts consisting of 2 material experts and 3 media experts. The number of samples used was 57 students. The instrument used was a media assessment questionnaire for media experts, material experts, and students. The data collection technique used was observation to PGSD students, Prof. Muhammadiyah University. Dr. HAMKA (consulting material and providing questionnaires for Android smartphone users) and providing expert validity questionnaires and student responses.

Validation of the BAGUR'SD teaching material website and the materials available by the validation of media experts and material experts were then analyzed by percentage descriptive techniques with the formula Sudijono in Khairunnisa [13].

\section{$P=\mathrm{F} / N \times 100 \%$}

Information:

$\mathrm{F}=$ The percentage of which is being sought

$\mathrm{N}=$ Number of Cases (number of frequencies / multiply individuals)

$\mathrm{P}=$ percentage number

Questionnaire data processing using a Likert scale, along with scoring Sudijono [14]. 
TABLE 1. Percentage Range and Media Eligibility Criteria

\begin{tabular}{cc}
\hline Percentage Range & Criteria \\
\hline $\mathbf{8 6 \%}-\mathbf{1 0 0 \%}$ & Sangat Baik \\
$\mathbf{7 6 \%}-\mathbf{8 5 \%}$ & Baik \\
$\mathbf{6 0 \%}-\mathbf{7 5 \%}$ & Cukup \\
$\mathbf{5 5 \%}-\mathbf{5 9 \%}$ & Tidak Baik \\
\hline
\end{tabular}

\section{RESULTS AND DISCUSSION}

The resulting product is made using 8GB RAM hardware specifications and the Windows Home operating system Lengue Babit.. This media is called Media Website BAGUR'SD with the website link https://bagursd.000webhostapp.com/. All components prepared in the design stage are then assembled into a single system using the Suscime Text 3 software. These components are assembled based on the storyboard that has been made previously with the components being RPP, Teacher's Book, Student Book, Study PPT, Study Video, and UHAMKA Student Work. The main homepage of the website can be seen in Image 1 below.

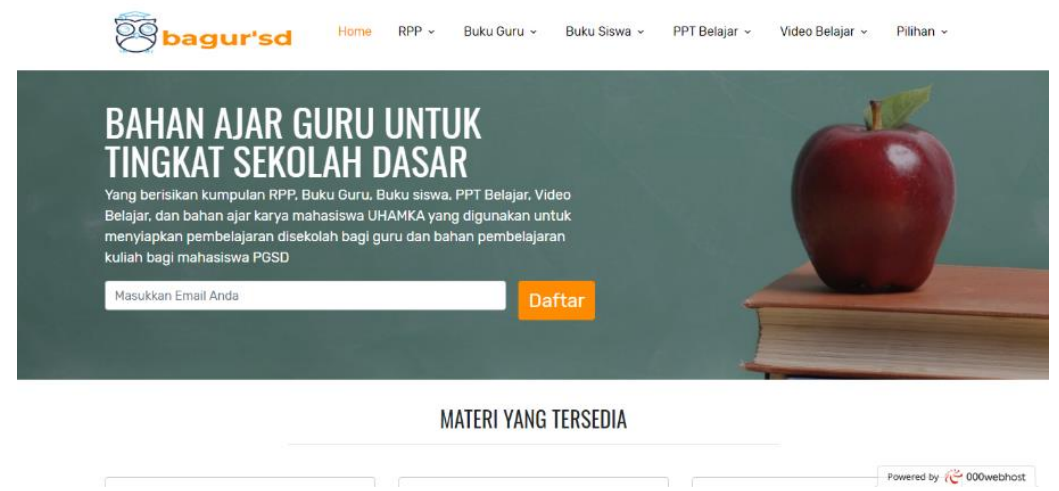

FIGURE 2. Main Homepage of a Website

In general, the results of the assessment or validation from material experts and media experts as well as the results of implementation or trials on students can be seen in the table below.

TABLE 2. Validation Results of Material Experts, Media Experts, and Implementation

\begin{tabular}{ccc}
\hline Validation and Implementation Results & Percentage (\%) & Predicate Per Aspect \\
\hline Material Validation & $91,25 \%$ & Very Good \\
Media Validation & $88,54 \%$ & Very Good \\
Implementation & $88,49 \%$ & \\
\hline
\end{tabular}

The results from the material experts obtained a percentage score of $91.25 \%$ in the very good category, then the results of the validation by the media experts obtained a percentage score of $88.54 \%$ with the very good category. Implementation in PGSD FKIP UHAMKA students, the quality of the website was $88.49 \%$ with a very good category, so the website was suitable for use in learning.

Furthermore, the results of the media eligibility assessment by material experts and media experts in every aspect can be seen in Table 2 and Table 3 below. 
TABLE 3. Website Eligibility Assessment by Material Experts

\begin{tabular}{ccc}
\hline Aspect & Perscentage (\%) & Predicate Per Aspect \\
\hline Material Aspect & $89,28 \%$ & Very Good \\
Learning Aspect & $95,83 \%$ & Very Good \\
\hline
\end{tabular}

The quality of learning media in terms of material aspects is $89.28 \%$ with very good categories, in terms of learning aspects of $95.83 \%$ with very good categories. In total, the quality of the learning media translated by two material experts was $91.25 \%$ with the very good category.

TABLE 4. Website Eligibility Assessment by Media Experts

\begin{tabular}{ccc}
\hline Aspek & Percentage (\%) & Predicate Per Aspect \\
\hline Display Aspect & $86,11 \%$ & Very Good \\
Writing Aspect & $94,44 \%$ & Very Good \\
Software Engineering Aspect & $88,54 \%$ & Very Good \\
\hline
\end{tabular}

The quality of the website "BAGUR'SD" in terms of appearance aspect is $86.11 \%$ with very good category, in terms of the writing aspect of $94.44 \%$ in the very good category, and in terms of software engineering aspects of $88.54 \%$ with very good category. Overall, the quality of the website assessed by three media experts was $88.73 \%$ with a very good category.

Furthermore, the implementation is carried out by distributing broadcasts containing the "BAGUR'SD" website link which can be accessed directly. Then the google form link replaces the direct distribution of questionnaires due to the Covid-19 pandemic. Website testing via online is carried out randomly to active students from the beginning to the end of the semester to determine the quality of the website in each aspect can be seen in Table 4.

TABLE 5. The Results of Testing the Quality of Learning Media by Respondents

\begin{tabular}{ccc}
\hline Aspect & Percentage (\%) & Predicate Per Aspect \\
\hline Display Aspect & $87 \%$ & Very Good \\
Writing Aspect & $87 \%$ & Very Good \\
Software Engineering Aspect & $89 \%$ & Very Good \\
\hline
\end{tabular}

As seen from the results per aspect, the display aspect is $87 \%$ very good category, $87 \%$ writing aspect is very good category, and software engineering aspect $89 \%$ is very good category. The overall results obtained were $88.49 \%$ in very good category.

Based on the research conducted, this development research is in the form of a website that contains complete teaching materials from grade one to grade six at the elementary school level in the form of lesson plans, teacher books, student books, learning videos, and PowerPoint which is named "BAGUR'SD". The BAGUR'SD website has advantages and disadvantages as a learning media. The advantages of the website are: (1) The BAGUR'SD website is a learning media for almost all courses that are contained in one link and can be easily accessed via a smartphone or laptop. (2) The BAGUR'SD website is a website that is not limited by time and space. (3) The BAGUR'SD website can be used repeatedly and teaching materials can be updated according to applicable provisons. (4) The BAGUR'SD website can be used to accommodate the work of students of the PGSD FKIP UHAMKA study program in the form of teaching materials. (5) Webiste BAGUR'SD is the latest innovation in learning media using smartphone technology that can accommodate complete teaching materials. And the weakness is the media that is made needs to be refined again considering the ability of the researchers themselves. Things that need to be improved on the BAGUR'SD website include adding animation, use of sound, and visual effects to menu buttons and content.

\section{CONCLUSION}

Based on the development research that has been carried out, the development of the circulation system website media uses the Hannafi and Peck style which was 
tested at the UHAMKA FKIP on active students of the PGSD study program. The final product is a teaching material website or BAGUR'SD which consists of lesson plans, teacher books, student books, videos, and PowerPoint. The results of the material expert validation obtained a percentage score of $91.25 \%$ with a very good category seen from the usefulness of the website to help lectures because the material available on the website is very complete and can be updated, then the results of validation by media experts obtained a percentage score of $88,73 \%$ with very good category seen by expert opinion that the website is easy to access. The implementation for active students of the PGSD FKIP UHAMKA study program resulted in the quality of learning media of $88.49 \%$ with a very good category, seen from the number of people accessing the website because of its easy use and it was very useful in times of sophistication and the COVID-19 Pandemic. So that the media website BAGUR'SD is suitable to be used in helping students to study in almost all subjects during face-to-face or online lectures. With the technology literacy-based teaching materials through this website, it can help students achieve their learning goals as prospective teacher. It is hoped that it can further improve the quality of media development for other teaching materials through websites with more varied content, or develop the BAGUR'SD website even better.

\section{REFERENCES}

[1] Ninawati, M. (2017). Pengaruh Model Brain Based Learning Terhadap Kemampuan Berpikir Kreatif Matematik Siswa Pada Pembelajaran Matematika Kelas V Sdn Pekayon 15. Prosiding Kolokium Doktor Dan Seminar Hasil Penelitian, 93-100.

[2] Ninawati, M. (2018). Jurnal indria. Jurnal Indria, III(3), 212-220. http://journal.umpo.ac.id/index.php/indria/index

[3] Ninawati, M. (2019a). Efektivitas Model Pembelajaran Literasi Kritis Berbasis Pendekatan Konsep Untuk Meningkatkan Keterampilan
Menulis Kreati Siswa Sekolah Dasar. Jurnal Ilmiah Pendidikan Dasar, IV, 68-78.

[4] UNESCO. (2008). UNESCO ICT competency framework for teachers. UNESCO.

[5] Maryland State Department of Education. (2005). Maryland Technologi Education State Curriculum. marylandpublicschools.org

[6] Ninawati, M. (2019a). Efektivitas Model Pembelajaran Literasi Kritis Berbasis Pendekatan Konsep Untuk Meningkatkan Keterampilan Menulis Kreati Siswa Sekolah Dasar. Jurnal Ilmiah Pendidikan Dasar, IV, 68-78.

[7] Lestari. (2013). Pengembangan Bahan Ajar Berbasis Sesuai dengan Kurikulum Satuan Pendidikan. Akademia Permata.

[8] Ruhimat dkk. (2011). Kurikulum dan Pembelajaran. Rajawali press.

[9] Ridwan, S. (2011). Pengantar Statistik untuk Penelitian Sosial Ekonomi, Komunikasi, dan Bisnis. Alfabeta.

[10] Winarni, E. . (n.d.). Mengajar IPA Secara Bermakna. UNIB PRESS.

[11] Yuli Yanti, I., Pudjawan, I. K., \& Wayan Suwatra, I. (2020). Pengembangan Lembar Kerja Siswa Model Hannafin Anf Peck Untuk Meningkatkan Hasil Belajar Siswa. Journal of Education Technology, 4(1), 67. https://doi.org/10.23887/jet.v4i1.24094

[12] Sugiyono. (2015). Pengantar Statistik Pendidikan. Jakarta: Raja Grafindo Persada. Rajawali press.

[13] Khairunnisa, S., Amirullah, G., \& Ninawati, M. (2019). Pengembangan Media Pembelajaran Aplikasi Mobile Learning Berbasis Android Pada Mata Kuliah Konsep Dasar Ilmu Pengetahuan Alam. Jurnal Inovasi Pendidikan Dasar, 4(2), 4956.

[14] Sudijono, A. (2006). Sudijono, A. (2006). Pengantar Statistik Pendidikan. Jakarta: Raja Grafindo Persada: Rajawali press. Sugiyono. Rajawali press. 